DISTRIBUTION AND SOURCE OF BARIUM IN GROUND WATER AT

CATTARAUGUS INDIAN RESERVATION, SOUTHWESTERN NEW YORK

By Richard B. Moore and Ward W. Staubitz

U.S. GEOLOGICAL SURVEY

Water-Resources Investigations Report 84-4129

Prepared in cooperation with the

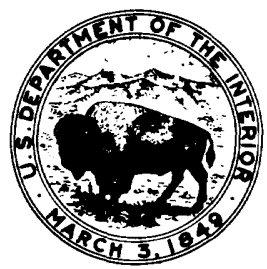

SENECA NATION OF INDIANS

Ithaca, New York

1984 
UNITED STATES DEPARTMENT OF THE INTERIOR

WILLIAM P. CLARK, Secretary

GEOLOGICAL SURVEY

Dallas L. Peck, Di rector

For additional information write:

U.S. Geologica1 Survey

$521 \mathrm{~W}$. Seneca Street

It haca, New York 14850

(607) 272-8722
Copies of this report may be purchased from:

Open-File Services Section Western Distribution $\mathrm{Br}$ anch Box 25425, Federal Center Denver, Colo. 80225 (303) 234-5888 
Abstract. . . . . . . . . . . . . . . . . . . . . 1

Introduction. . . . . . . . . . . . . . . . . . . . . 1

Purpose and scope. . . . . . . . . . . . . . . . 3

Acknowledgments. . . . . . . . . . . . . . . . . . 3

Methods . . . . . . . . . . . . . . . . . . . . 3

Water sampling . . . . . . . . . . . . . . . . . 3

Geology and stratigraphy. . . . . . . . . . . . . . . . . . 4

Physiographic setting . . . . . . . . . . . . . . . . . . . 4

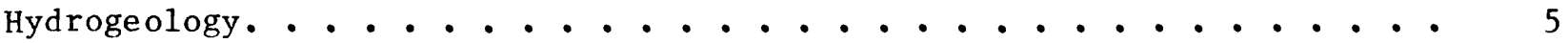

Bedrock aquifer. . . . . . . . . . . . . . . . . 5

Unconsolidated aquifer . . . . . . . . . . . . . . 5

Distribution of barium. . . . . . . . . . . . . . . . . . 8

Ground water .......................... 8

Surface water. . . . . . . . . . . . . . . . . 8

Possible sources of barium. . . . . . . . . . . . . . . 8

Cattaraugus Creek. . . . . . . . . . . . . . . . 9

Land surface ......................... 9

Barite drilling mud. . . . . . . . . . . . . . . 10

Gas wells tapping deep bedrock . . . . . . . . . . . . 10

Upper bedrock. . . . . . . . . . . . . . . . . 10

Barium solution processes . . . . . . . . . . . . . . . 11

Suggestions for further study . . . . . . . . . . . . . . . 13

Summary and conclusions . . . . . . . . . . . . . . . . 13

References cited....................... . . . . 13

\section{ILLUSTRATIONS}

Page

Figure 1.--Map showing location and physiographic regions of the study area . . . . . . . . . . . . . . . . ${ }_{2}$

2.--Geologic sections through Cattaraugus Indian Reservation . • 6

\section{PLATES}

(in pocket)

Plate 1.--Bedrock geology and distribution of barium concentrations in ground water at the Cattaraugus Indian Reservation.

2.--Surficial geology of the Cattaraugus Indian Reservation. 
TABLES

Page

Table 1.--Barium concentrations in water samples from Cattaraugus Creek at Gowanda, N.Y., November 1978 through September 1981 • • • 9

2.--Geologic logs of auger test holes. . . . . . . . . 10

3.--Chemical analyses of ground water from three wells having high barium concentrations, Cattaraugus Indian Reservation, N.Y. . . . . . . . . . . . . . . . . .

4.--Well inventory data and results of barium analysis, Cattaraugus Indian Reservation, Spring-Summer, 1982. . . .

\section{CONVERSION FACTORS AND ABBREVIATIONS}

The following factors may be used to convert inch-pound units of measurement to the International System of Units.

Multiply inch-pound unit

inch (in)

foot $(f t)$

mile (mi)

degree Fahrenheit $\left({ }^{\circ} \mathrm{F}\right)$ by

2.540

$3.048 \times 10^{-1}$

1.609

$5 / 9\left(F^{\circ}-32\right)$
To obtain SI unit

centimeter $(\mathrm{cm})$

meter $(\mathrm{m})$

kilometer $(\mathrm{km})$

degree Celsius $\left({ }^{\circ} \mathrm{C}\right)$

Abbreviations used in the text of this report include:

$$
\begin{aligned}
& \mathrm{mg} / \mathrm{L}, \text { milligrams per liter } \\
& \mathrm{ug} / \mathrm{L} \text {, micrograms per liter } \\
& \text { gal/min, gallons per minute } \\
& \mathrm{ml} \text {, milliliter }
\end{aligned}
$$




\title{
DISTRIBUTION AND SOURCE OF BARIUM IN GROUND WATER AT CATTARAUGUS INDIAN RESERVATION, SOUTHWESTERN NEW YORK
}

\author{
by Richard B. Moore and Ward W. Staubitz
}

\begin{abstract}
High concentrations of dissolved barium have been found in ground water from bedrock wells on the Seneca Nation of Indians Reservation on Cattaraugus Creek in southwestern New York. Concentrations in 1982 were as high as 23.0 milligrams per liter, the highest concentration reported from any natural ground-water system in the world. The highest concentrations are in a bedrock aquifer and in small lenses of saturated gravel between bedrock and the overlying till. The bedrock aquifer is partly confined by deposits of silt, clay, and till. The highest barium concentrations are attributed to dissolution of the mineral barite (BaSO4), which is in the bedrock and possibly in overlying silt, clay, and till. The dissolution of barite apparently is controlled by the action of sulfate-reducing bacteria, which alter the BaSO4 equilibrium by removing sulfate ions and permitting additional barite to dissolve.
\end{abstract}

Ground water from the overlying unconsolidated deposits and surface water in streams contain little or no barium. Because barium is chemically similar to calcium, it probably could be removed by cation exchange or treatments similar to those used for water softening.

\section{INTRODUCTION}

Barium is present naturally in the ground water of New York State. A recent study of public-water supplies in New York State reported that barium concentrations range from less than $0.001 \mathrm{mg} / \mathrm{L}$ to $2.3 \mathrm{mg} / \mathrm{L}$, with the highest values in western New York (Cartwright and Ziarno, 1980). The New York State drinkingwater standard for barium is $1.0 \mathrm{mg} / \mathrm{L}$. Ingestion of barium in high concentrations may result in vomiting, diarrhea, spasms, and in some cases, paralysis. The fatal dose of barium for man is reported to be 550 to $600 \mathrm{mg}$ (U.S. Environmental Protection Agency, 1976).

In 1981, the U.S. Environmental Protection Agency and the New York State Department of Health sampled two public-water supplies that obtain ground water from wells 6 miles apart on the Cattaraugus Indian Reservation (fig. 1). Results of the sampling showed barium concentrations of $21.5 \mathrm{mg} / \mathrm{L}$ in one system amd $6.13 \mathrm{mg} / \mathrm{L}$ in the other. Because the residents of the reservation rely on these two public water supplies and on many other private wells, an investigation of the high barium concentrations was begun.

Little research has been done to identify the cause of high barium concentrations in ground water. The Cattaraugus Indian reservation, which lacks industries or other obvious manmade sources of barium, made an ideal area for study. In the spring and summer of 1982, the U.S. Geological Survey, in cooperation with the Seneca Nation of Indians, conducted a single sampling of 100 wells and springs on the reservation to determine the distribution and concentration of barium in ground water. 


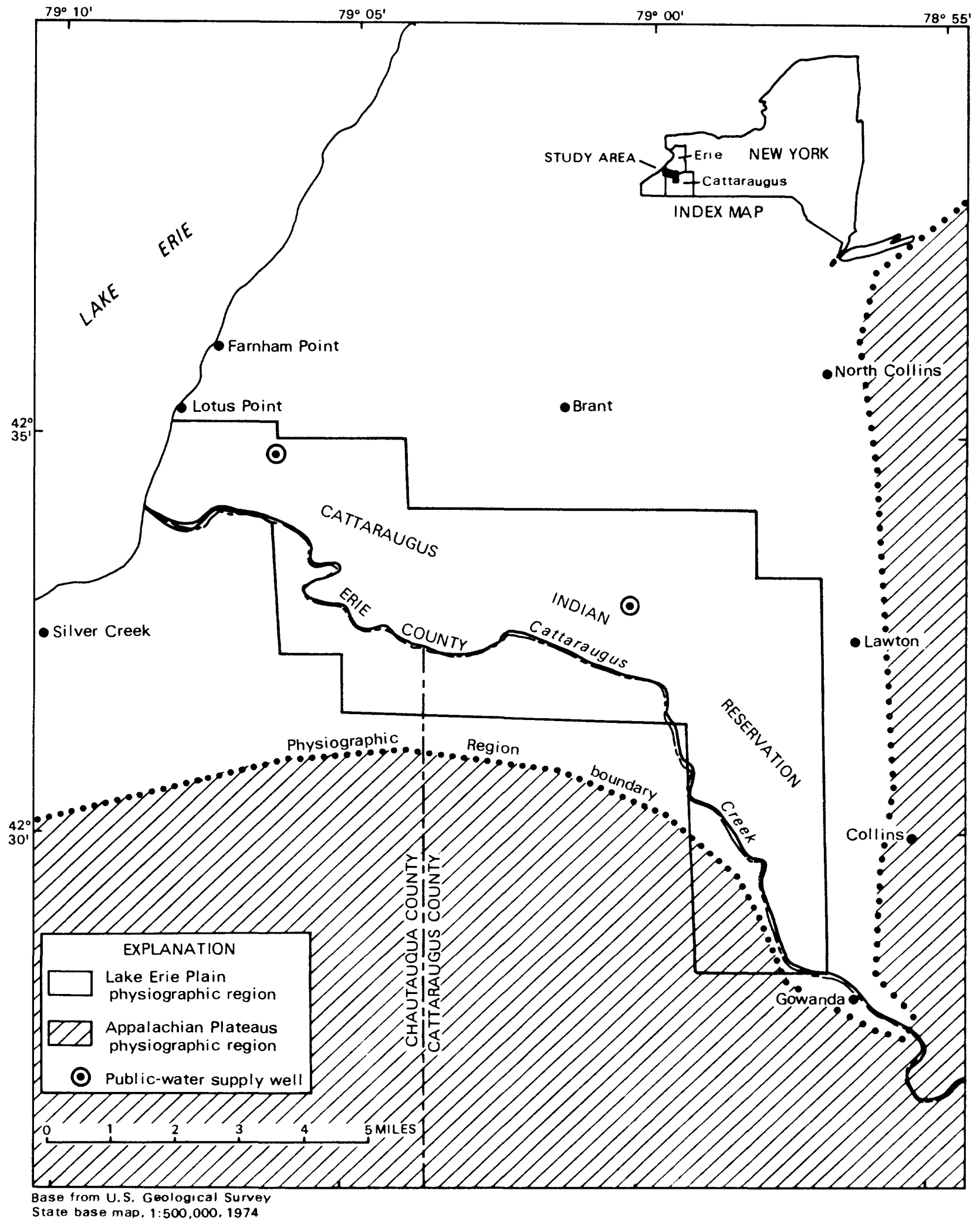

Figure 1.--Location and physiographic regions of the study area. 


\section{Purpose and Scope}

This report describes the results of a study to obtain, from a single sampling of ground water from 100 representative wells and springs, information on the distribution and source of barium in ground water at the Cattaraugus Indian Reservation. The report also describes the geochemical processes involved in barium mobilization and presents detailed maps of the surficial and bedrock geology, including two geologic sections. Also included is a tabulation of water-quality and well data and geologic logs of two test holes.

\section{Acknowledgments}

This project was coordinated with the Seneca Nation of Indians through the Seneca Nation Planning Department. Supplemental data gathered for this study were provided by the Seneca Nation, local well drillers and consultants, and the residents of the Cattaraugus Indian Reservation. Thanks are extended to all of the above and to Sam Bradshaw of the Indian Health Service, Dr. Windsor Sung of the University of New Hampshire, and to other reviewers of this manuscript.

\section{METHODS}

The study entailed a literature search, compilation of available geohydrologic data, and a sampling program to test water from 100 we1ls and springs on the reservation for barium concentration. This approach was used on the assumption that the barium concentrations would be highest near or downgradient from the source(s) of the barium and that the distribution would indicate the location and nature of the source.

\section{Water Sampling}

Well-water samples generally were taken from household taps that were used frequently. If a tap was not used frequently, water was run for several minutes before sampling to remove all long-standing or stagnant water. Water from a few of the wells sampled had been treated by water softening; samples from those households were taken from taps yielding untreated water wherever possible.

All samples were collected in 100-mL acid-washed polyethylene bottles, acidified with nitric acid, and shipped to the U.S. Geological Survey Central Laboratory in Atlanta, Ga., where total barium content was determined by atomic absorption spectrometry. If available, data on well depth, well diameter, aquifer, well owner and driller, $\mathrm{pH}$, and specific conductance also were compiled in the field for each well sampled. These data are tabulated in table 4 (at end of report).

Filtered and unfiltered samples also were collected from three wells known to have high barium concentrations to obtain more detailed information on the water chemistry. The filtered samples were analyzed for dissolved barium, calcium, chloride, fluoride, magnesium, nitrogen, potassium, silica, sodium, strontium, sulfate, and total alkalinity. The results (table 3 ) were then used 
as input for the WATOF computer program (P1ummer, Jones, and Truesde11, 1976) to determine the saturation level of the ground water with respect to common barium-containing minerals. The unfiltered samples were analyzed for total barium and total sulfide to determine whether barium is in the dissolved or. suspended state.

\section{GEOLOGY AND STRATIGRAPHY}

Auger holes were drilled adjacent to the two wells from which the high barium concentrations were initially reported. Sediment and bedrock samples were collected from the auger holes to verify the stratigraphy near the wells. The logs of the auger holes are included in table 2 ( $p .10)$.

Maps of the bedrock geology (p1, 1) and the surficial geology (p1.2) of the area and two geologic sections (fig. 2) we re drawn to delineate the geologic formations and surficial deposits and to identify their relationship to well locations and the distribution of barium.

\section{PHYSIOGRAPHIC SETTING}

The Cattaraugus Indian Reservation occupies $60 \mathrm{mi}^{2}$ of the Cattaraugus Creek valley southeast of Lake Erie (fig. 1). Cattaraugus Creek has a drainage area of about $450 \mathrm{mi} 2$ and flows westward to Lake Erie, draining several north-southtrending tributary valleys in the Appalachian Plateaus upland. This area has a continental climate with cold winters and warm summers. The mean annual precipitation is about 37 inches; the mean annual temperature is about $46^{\circ} \mathrm{F}$ (U.S. Department of Commerce, 1982).

The western and central parts of the reservation are within the Erie Lake Plain of the Central Lowlands, and the southeastern part is in the southern New York Uplands of the Appalachian Plateaus (Tesmer, 1975). The low-1ying Erie Lake Plain is a relatively flat, gently sloping surface that rises eastward from Lake Erie to the base of the Appalachian Plateaus. The central part of the reservation is in an embayment of the Erie Lake Plain into the uplands (Muller, 1963); it is characterized by a relatively broad, flat valley bordered on the north and south by low-lying bedrock hills. The southeastern part of the reservation is at the base of the Appalachian Plateaus and is characterized by gently rolling hills.

Relief on the reservation ranges from $473 \mathrm{ft}$ along the shore of Lake Erie to $1,040 \mathrm{ft}$ in the uplands. The Erie Lake Plain occupies the area between $473 \mathrm{ft}$ and $850 \mathrm{ft}$ (Muller, 1963).

The bedrock that underlies the unconsolidated deposits consists of sedimentary rocks of the Canadaway and Java Formations and the West Falls Group of Devonian age (Buehler and Tesmer, 1963 and Tesmer, 1975). These strata are essentially undeformed and dip gently to the south-southeast. Plate 1 depicts the bedrock geology and includes a brief description of geologic units. 
Unconsolidated deposits overlie bedrock both in the Cattaraugus Creek valley and along the hillside. The valley is partly filled with as much as $350 \mathrm{ft}$ of lacustrine sediments of fine sand, silt, and clay that were deposited in icedammed lakes that preceded Lake Erie (fig. 2). After the lakes receded, Cattaraugus Creek deposited alluvial sand, gravel, and silt over the lacustrine deposits. The bedrock hills are covered in most places by a thin layer of till. A map of the surficial geology is shown in plate 2; the stratigraphy along two geologic cross sections is shown in figure 2 .

\section{HYDROGEOLOGY}

Water supplies on the reservation are obtained primarily from two kinds of aquifers--confined bedrock and unconfined, unconsolidated sand and grave 1 deposits. A third type, consisting of scattered pockets or layers of sand and gravel buried beneath major confining units, may yield small quantities of water, but this type is not widely used in the area.

\section{Bedrock Aquifer}

The bedrock aquifer is recharged by rain and snowmelt on the surrounding hillsides, which in some areas extend beyond the reservation boundaries, and also along the valley axis by upward movement of deep ground water, which is of poorer quality than that from the hillsides. The bedrock aquifer discharges ground water upward into the surficial valley-fill deposits, as indicated by artesian heads along the valley axis. The bedrock is mostly confined by silt and clay deposits that formed in late-glacial ice-dammed lakes and were then reworked and redeposited as lodgment till by glaciers. These silt and clay deposits have low permeability and therefore limit the exchange of water between the bedrock and the surficial sand and gravel aquifer.

Few we1ls in the area extend more than 200 feet into the bedrock because the mineral content of the ground water increases beyond acceptable limits below that depth.

\section{Unconsolidated Aquifer}

The unconsolidated aquifer in the area is composed of saturated sand and gravel deposits at or near land surface that interfinger with or overlie the silt and clay layers ( $\mathrm{pl}, 1$ and 2). These unconsolidated deposits consist of deltaic sand and gravel in the southwestern part of the reservation, beach sand and gravel scattered locally throughout the reservation, and alluvial sand and gravel in low-lying areas near Cattaraugus Creek and other streams ( 1 1. 2). These deposits are recharged by precipitation wherever they are exposed at land surface and locally from the upper bedrock aquifer. 

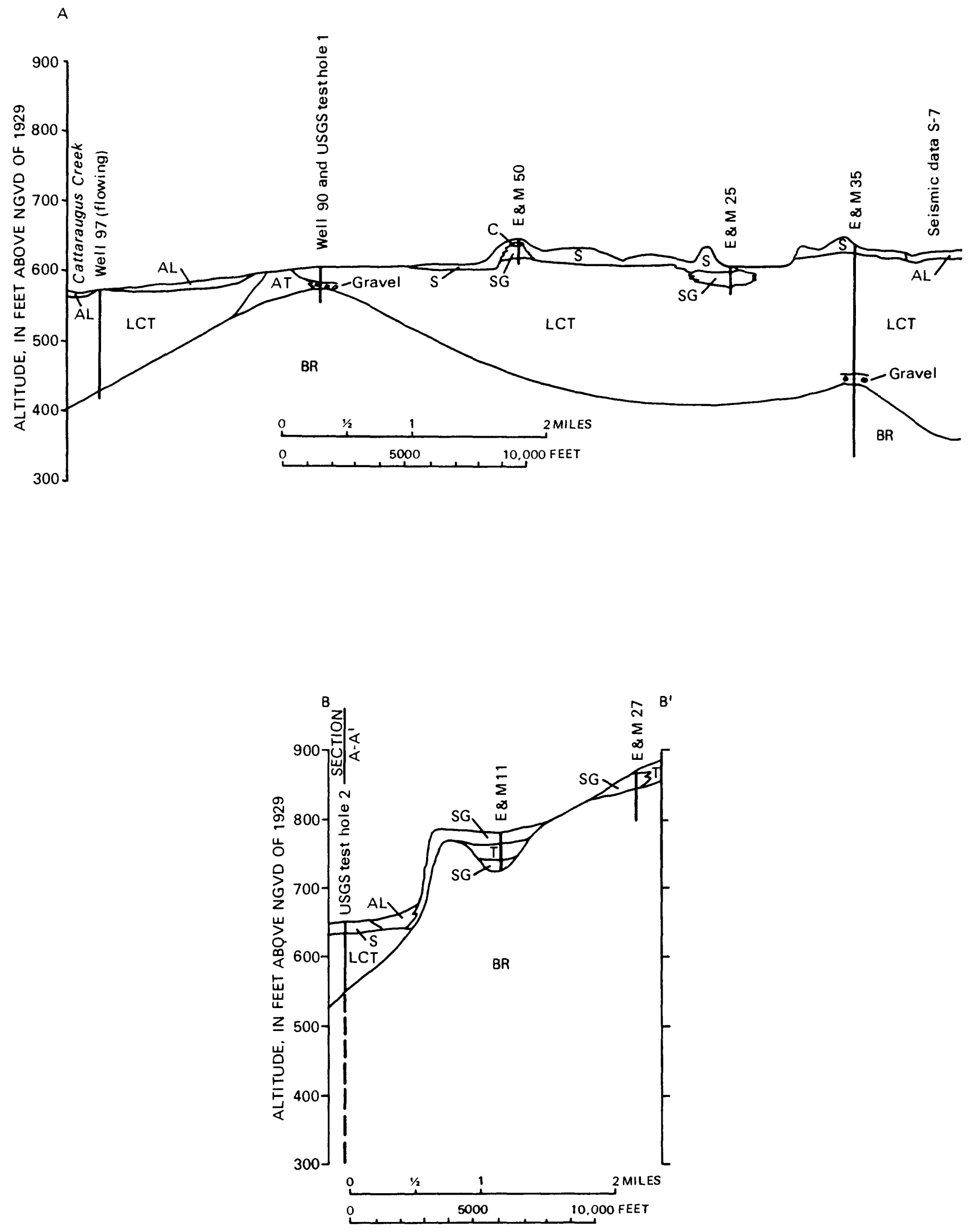

Figure 2.--Geologic sections through Cattaraugus Indian Reservation. 


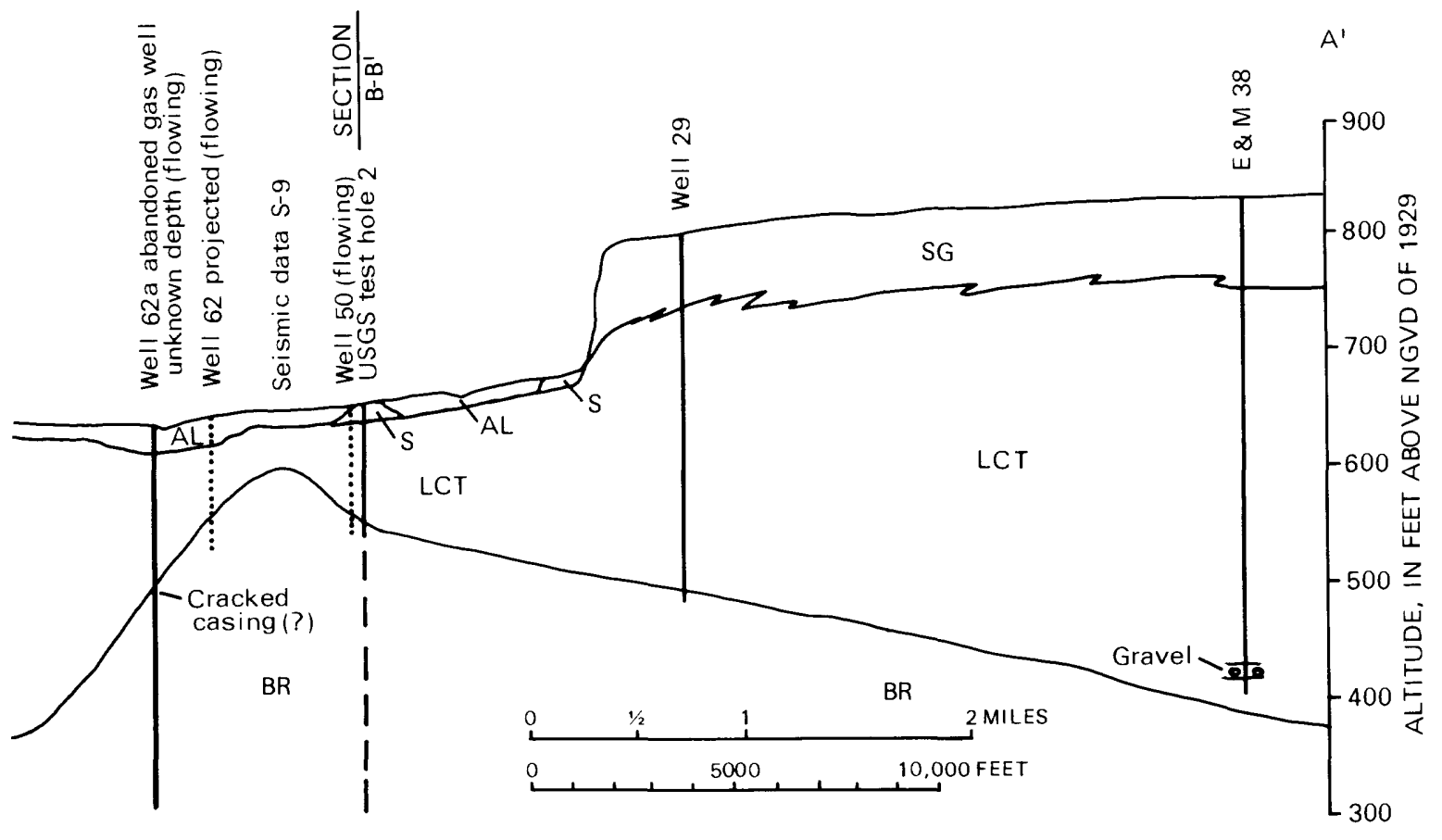

EXPLANATION

AL Alluvium; deposited by streams; low permeability where silty, moderate permeability where sandy or gravely

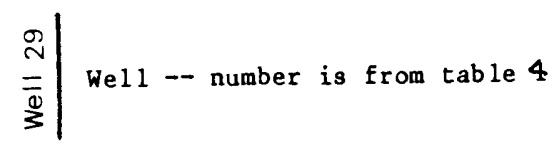

SG Sand and gravel; undifferentiated, high permeability

S Sand, undifferentiated; high permeability

We 11 of unknown depth and stratigraphy -number is from table 4

C Clay; low permeability

LCT Clay with silt; deposited in late-glacial ice-dammed lakes, partly reworked and redeposited as lodgment till; low permeability

Ablation till; low permeability where clayey, moderate permeability where sandy

Till, undifferentiated; low permeability where clayey, moderate permeability where sandy

Test hole -- U.S. Geological Survey data on file with the USGS, Ithaca, N.Y.

Bedrock undifferentiated; moderate permeability due to

fractures near the upper bedrock surface

1 Localized layers of water-bearing gravel occur within or beneath this clay unit as labeled in section $A-A^{\prime}$. 


\section{DISTRIBUTION OF BARIUM}

\section{Ground Water}

Barium concentration in samples from wells ranged from less than $0.5 \mathrm{mg} / \mathrm{L}$ to more than $23.0 \mathrm{mg} / \mathrm{L}$. The highest barium concentration found during the study, $23 \mathrm{mg} / \mathrm{L}$, was the highest reported to date from any natural ground-water system in the world. The second highest in the world, $19.4 \mathrm{mg} / \mathrm{L}$, was in a ground-water sample from the Crimean Steppe zone of the Soviet Union (Terdovidov, 1971).

The areal distribution of barium as depicted on plate 1 indicates that wells with high barium concentrations are distributed randomly throughout the reservation. They are not clustered along Cattaraugus Creek nor around gas wells, nor are they limited to specific bedrock units.

The hydrologic, geologic, and chemical data on well and spring samples in table 4 (at end of report) indicate that:

(1) High barium concentrations are mainly in wells that penetrate the bedrock aquifer. Of the 28 wells with barium concentrations in excess of $0.5 \mathrm{mg} / \mathrm{L}$, all are drilled wells, of which 12 were reported by the owners to penetrate bedrock. The remaining 16 are assumed to penetrate bedrock because they are either deep or near bedrock outcrops.

(2) Many of the wells with high barium concentrations also have a hydrogen sulfide odor.

(3) One well (site 65, p1.1) having high barium concentrations taps a buried pocket of sand and gravel.

(4) The 26 wells and springs known to tap the surficial sand and gravel aquifer yield water with low barium concentrations (less than $0.5 \mathrm{mg} / \mathrm{L}$ ).

\section{Surface Water}

The U.S. Geological Survey has collected water-quality samples regularly since November 1978 from Cattaraugus Creek at Gowanda, 1/2 mile upstream from the Reservation (fig. 1), at high, medium, and low flows. Results of the barium analyses of samples taken from November 1978 through September 1981 are summarized in table 1 ; the concentrations in all samples were low (less than 0.2 $\mathrm{mg} / \mathrm{L})$. Because no industries or other likely sources of barium are between the sampling point in Gowanda and the reservation, the barium concentrations measured in Gowanda are probably similar to those in Cattaraugus Creek where it passes through the reservation.

\section{POSSIBLE SOURCES OF BARIUM}

Several possible sources of the high barium levels in ground water were considered in this study; conclusions based on the results of the water-quality sampling are described in the following paragraphs. 
Table 1.--Barium concentrations in water samples from Cattaraugus Creek at Gowanda, N.Y., November 1978 through September 1981.

[Data from U.S. Geological Survey, 1980, 1981, 1982. Location is shown in fig. 1. Dash indicates no data.]

\begin{tabular}{rcc}
\hline $\begin{array}{c}\text { Date } \\
\text { (mo-day-yr) }\end{array}$ & $\begin{array}{c}\text { Total } \\
\text { recoverable } \\
\text { barium } \\
(\mathrm{mg} / \mathrm{L})\end{array}$ & $\begin{array}{c}\text { Dissolved } \\
\text { Barium } \\
(\mathrm{mg} / \mathrm{L})\end{array}$ \\
\hline $11-09-78$ & 0.10 & 0.10 \\
$1-10-79$ & .10 & $<.05$ \\
$4-10-79$ & $<.05$ & $<.05$ \\
$6-21-79$ & .10 & .06 \\
$11-26-79$ & -- & .05 \\
$1-22-80$ & .20 & .07 \\
$4-29-80$ & $<.05$ & .05 \\
$6-18-80$ & .10 & .07 \\
$9-04-80$ & .10 & .10 \\
$11-13-80$ & .10 & .05 \\
$3-18-81$ & .10 & .10 \\
$7-15-81$ & .10 & .07 \\
$9-17-81$ & .10 & .10 \\
\hline
\end{tabular}

\section{Cattaraugus Creok}

If barium in ground water originates from seepage from Cattaraugus Creek and surface-water sources upstream from the reservation, high barium concentrations would be found in water samples from the creek and from wells adjacent to the creek wherever natural or induced recharge may occur. The distribution of barium shown in plate 1 , however, does not indicate a clustering of high barium concentrations in wells near the creek, nor were high concentrations detected in samples from the creek ( $t a b l e ~ 1)$. Therefore, Cattaraugus Creek is probably not the source.

\section{Land Surface}

If barium originates from the dumping of barium-rich substances on the land surface, large barium concentrations would be expected in shallow wells near the contaminated areas. Plate 1 , however, indicates that the high barium concentrations are widespread, not localized in any specific area. Also, high barium concentrations were found in water from the deep wells, not the shallow wells, which are more vulnerable to contamination from surface sources. For example, wells 50, 51a, and 51b (table 4 and pl. 1) are close to one another but have considerably different barium concentrations. The deeper well (50) is the only one with a high concentration of barium $(23 \mathrm{mg} / \mathrm{L})$. This well penetrates more than $80 \mathrm{ft}$ of relatively impermeable silt and clay, as determined from test boring 2 (table 2) before reaching the water-bearing unit (presumably bedrock). These observations seem to rule out surface contamination as the source of barium. 
Table 2. Geologic logs of auger test holes.

[Locations are shown in pl. 2.]

TEST HOLE 1

Located $50 \mathrm{ft}$ north of well 90. Log from sample study by R. B. Moore, U.S. Geologica1 Survey.

0-6 ft Clayey silt, brown, breaks apart, moist

6-15 ft Clay, some silt, brown to gray, very pliable, saturated

15-26 ft Ti11, mostly clay, pebbles and cobbles, gray, nearly dry

$26.5 \mathrm{ft}$ Refusal

TEST HOLE 2

Located about $200 \mathrm{ft}$ west of well 50. Log from sample study by R. B. Moore, U.S. Geological Survey.

0-13 ft Grave1, some silt and cobbles, brown, saturated at $7 \mathrm{ft}$

13-88 ft Clay, with silt, intermittent sand layers, gray, pliable, saturated $88 \mathrm{ft} \quad$ Bottom of hole; no refusal

\section{Barite Drilling Mud}

If barium originates from barite drilling mud used during the drilling of gas and water wells, large barium concentrations would be expected only in wells in which barite drilling mud was used. However, several wells with high barium concentrations were constructed by procedures that did not use drilling mud (Frey Well Drilling, written commun., 1982, and Edwards and Moncriel, oral commun., 1982), which indicates that drilling mud is not the source.

\section{Gas Wells Tapping Deep Bedrock}

If deep ground water containing high barium concentrations we re leaking upward into the aquifers along the casings of active or abandoned gas we11s, large barium concentrations would be expected in water wells close to or downgradient from the gas wells. However, the wells with high barium concentrations were not clustered around gas wells nor were they aligned downgradient from them. Therefore, gas wells do not appear to serve as a conduit for barium contamination.

\section{Upper Bedrock}

Results of the water-quality sampling indicate high barium concentrations to be widespread among wells tapping the bedrock aquifer. Because no other source of barium has been identified, the high barium concentrations are probably derived from the dissolution of barium minerals in the upper bedrock. 
Barite ( $\mathrm{BaSO} 4)$ and witherite $(\mathrm{BaCO} 3)$ are the most common minerals containing barium and are, therefore, the most probable sources of barium; their solubilities are the most probable controls on barium concentrations in ground water.

\section{BARIUM SOLUTION PROCESSES}

In an attempt to verify the state of saturation of ground water with respect to barite and witherite, the WATEQF program (Plummer, Jones, and Truesde11, 1976) was used to relate the ion-activity products (IAP) of barite and witherite in waters from the three wells (table 3 ) having the highest barium concentration to the solubility products (KT) of the minerals. From the relationship, a value of $\log \mathrm{IAP} / \mathrm{KT}$ greater than zero indicates oversaturation, a value less than zero indicates undersaturation, and a value of zero indicates saturation. The log $\mathrm{IAP} / \mathrm{KT}$ values obtained were:

We11 $50 \quad$ We11 62a Well 90

\begin{tabular}{lcrr}
\hline Barite $\left(\mathrm{BaSO}_{4}\right)$ & $*$ & 0.3 & 0.7 \\
Witherite $\left(\mathrm{BaCO}_{3}\right)$ & -0.7 & -1.8 & -1.5 \\
\hline
\end{tabular}

* Concentration of sulfate was less than the detection limit, therefore, the IAP could not be calculated.

Thus, water at all three wells was undersaturated with respect to witherite, and water in wells $62 \mathrm{a}$ and 90 was oversaturated with respect to barite, indicating that barium concentrations in the waters are probably controlled by the solubility of barite. This result and the reported occurrences of barite elsewhere in the same type of rocks that underlie the reservation (Ha11, 1843) strongly suggest barite to be the barium source.

Additionally, if barite is the primary source of barium, one would expect the molar concentration of sulfate to be similar to that of barium from the $1: 1$ stoichiometric relationship expressed in the following equation:

$$
\mathrm{BaSO}_{4} \leftrightharpoons \mathrm{Ba}^{++}+\mathrm{SO}_{4}=
$$

Additional sources of sulfate such as gypsum would make the sulfate concentrations even greater. However, the concentrations of sulfate in the three wells having the highest barium concentrations were very low (table 3 ). A possible explanation of the low sulfate concentrations may be the action of sulfate-reducing bacteria. In an anaerobic environment, these bacteria use sulfate as an oxygen source for metabolizing organic material. In the process, sulfate is reduced to sulfide, as indicated in equation 2, and the sulfide may eventually escape from solution as hydrogen sulfide gas (Hem, 1970), as follows:

$$
\mathrm{SO}_{4}=+\mathrm{CH}_{4} \longrightarrow \mathrm{HS}^{-}+\mathrm{HCO}_{3}^{-}+\mathrm{H}_{2} \mathrm{O}
$$

The odor of hydrogen sulfide gas was noted in many of the wells sampled, including those with high barium concentrations. 
Additional observations support this explanation. Sulfate concentrations in the ground water of three wells were between $<1$ and $2 \mathrm{mg} / \mathrm{L}$ ( table 3 ), whereas those in precipitation in the area range from 2 to $25 \mathrm{mg} / \mathrm{L}$ (Archer and others, 1968 , p. 19). Because precipitation is the main source of recharge for ground water in the area, either sulfate concentrations in precipitation were less at the time of deposition or sulfate is being removed from the ground water. The organic compounds necessary to support the sulfide-reducing bacteria are common in most shale bedrock and have been observed in the Dunkirk shale ( 1.1 1) (Tesmer, 1975, p. 34). Also, natural gas produced by anaerobic bacteria that require an environment similar to that of sulfide-reducing bacteria has been reported to be emitted from several water wells in the area (table 4). Together, these observations lead to the conclusion that the bedrock in the area has the proper anaerobic environment and food source to support sulfate-reducing bacteria, which are, in fact, removing sulfate from the ground water.

This conclusion has chemical implications significant to this study. If sulfate is being removed from solution, equilibrium will shift to favor the dissolution of barite, which will increase the amount of barium in solution. This process would explain the unusually high concentration of barium measured in the ground water of the Cattaraugus Indian Reservation.

The high barium concentrations in the water can probably be reduced to more acceptable levels by standard water-treatment techniques. Because barium has the same positive (++) charge as calcium and magnesium, barium should be removed from solution by water softening or ion exchange. Water softening appeared to be effective in reducing the barium concentration of water from we 1150 . The barium concentration in we 1150 decreased from $23 \mathrm{mg} / \mathrm{L}$ to $0.3 \mathrm{mg} / \mathrm{L}$ after treatment by water softening (table 4 ).

Table 3.--Chemical analyses of ground water from the three wells having high barium concentrations, Cattaraugus Indian Reservation, N.Y.

[We11 locations are shown on plate 1. A11 concentrations are in milligrams per liter. Samples collected April 23, 1982].

\begin{tabular}{lccc}
\hline & \multicolumn{3}{c}{ Well Number } \\
\cline { 2 - 4 } Constituent or Property & 50 & $62 \mathrm{a}$ & 90 \\
\hline & 7.2 & 7.1 & 6.8 \\
pH (field) & 200 & 240 & 340 \\
Total alkalinity [as CaC03] & 23.0 & 2.5 & 6.9 \\
Barium, dissolved & 28.0 & 36.0 & 64.0 \\
Calcium, dissolved & 9.8 & 110 & 74.0 \\
Chloride, dissolved & .3 & .4 & .3 \\
Fluoride, dissolved & 7.6 & 15.0 & 27.0 \\
Magnesium, dissolved & .1 & .1 & .1 \\
Nitrogen, dissolved & 2.4 & 1.8 & 3.2 \\
Potassium, dissolved & 12.0 & 15.0 & 15.0 \\
Silica, dissolved & 46.0 & 110 & 71 \\
Sodium, dissolved & 1.30 & 0.86 & 2.00 \\
Strontium, dissolved & $<1.0$ & 2.0 & 2.0 \\
Sulfate, dissolved & $<.5$ & .5 & $<.5$ \\
Sulfide, total & & &
\end{tabular}




\section{SUGGESTIONS FOR FURTHER STUDY}

If water-supply needs increase, it would be desirable to obtain more data on the quality and quantity of water available on the reservation and on the distribution of barium in various aquifers. Important questions to address are (1) whether barite minerals occur in the confining lodgment till and lake silts and clays that overlie the bedrock, and (2) whether increased development of the sand and gravel aquifers will draw barium-enriched water from the underlying bedrock. Future studies should also determine precisely the sulfate and sulfide concentrations in relation to the barium concentration in the ground water. Studies using the isotopes of sulfur $\left({ }^{34} \mathrm{~S}\right.$ and $\left.{ }^{32} \mathrm{~S}\right)$ in the ground water would be helpful in determining whether bacteria are indeed reducing sulfate to sulfide.

\section{SUMMARY AND CONCLUSIONS}

Ground water on the Cattaraugus Reservation contains dissolved barium concentrations as high as $23 \mathrm{mg} / \mathrm{L}$. The high barium concentrations are primarily in water from the upper bedrock aquifer, although some are in water from isolated deep sand and gravel deposits. Water from the unconfined, unconsolidated deposits contains little or no barium. Results from a sampling of 100 wells and springs in the summer of 1982 indicate that the barium originates from dissolution of the mineral barite (BaSO4) in the bedrock. The removal of sulfate by sulfatereducing bacteria allows unusually high barium concentrations to be reached before the solubility of barite serves to control the barium concentrations. High barium concentrations could probably be decreased by water-softening treatment.

Treatment of water from wells with the high barium concentrations may be feasible because barium has the same positive $(++)$ charge as calcium and could be removed by water softening or ion exchange.

\section{REFERENCES CITED}

Archer, R. J., LaSala, A. M., Jr., and Kammerer, J. C., 1968, Chemical quality of streams in the Erie-Niagara basin New York: State of New York Conservation Department Water Resources Commission, Basin Planning Report ENB-4, $104 \mathrm{p}$.

Buehler, E. J., and Tesmer, I. H., 1963, Geology of Erie County: Buffalo Society of Natural Sciences Bulletin, v. 21, no. 3, 118 p.

Cartwright, R. H. and Ziarno, J. A., 1980, Chemical quality of water from community systems in New York, November 1970 to May 1975: U.S. Geological Survey Water-Resources Investigations 80-77, $444 \mathrm{p}$.

Ha11, James, 1843, Geology of New York, part 4, comprising the survey of the fourth geological district: Albany, Carro11 and Cook Printers, 684 p. 


\section{REFERENCES CITED (continued)}

Hem, J. D., 1970, Study and interpretation of the chemical characteristics of natural water, second edition: U.S. Geological Survey Water-Supply Paper $1473,363 \mathrm{p}$.

Muller, E. H., 1963, Geology of Chautauqua County, New York: New York State Museum and Science Service Bulletin 392, 60 p.

, 1977, Quartenary geology of New York, Niagara sheet: New York State Museum and Science Service, Map and Chart Series No. 28, 1 sheet.

Plummer, L. N., Jones, B. F., and Truesde11, A. H., 1976, WATEQF - a Fortran IV version of WATEQF, a computer program for calculating chemical equilibrium of natural waters: U.S. Geological Survey Water-Resources Investigations $76-13,63 \mathrm{p}$.

Terdovidov, A. S., and Chupis, N. Y., 1971, Barium and strontium in groundwaters of mesozoil-cenozoil sedimentary deposits in the Crimean steppe zone: Geokhimiya, no. 11, p. 1343-1352.

Tesmer, I. H., 1975, Geology of Cattaraugus County, New York: Buffalo Society of Natural Sciences Bulletin 27, 105 p.

U.S. Department of Commerce, National Oceanic and Atmospheric Administration, 1982, Climatological Data Annual Summary - New York, v. 94, no. 13, 30 p.

U.S. Environmental Protection Agency, 1976, Quality criteria for water: Washington, D.C., $256 \mathrm{p}$.

U.S. Geological Survey, 1980, Water resources data for New York, water year 1979: U.S. Geological Survey Water-Data Report NY-79, v. 1, 538 p.

1981, Water resources data for New York, water year 1980: U.S. Geological Survey Water-Data Report NY-80, v. 3, 247 p.

1982, Water resources data for New York, water year 1981: U.S. Geological Survey Water-Data Report NY-81, v. 3, 223 p. 


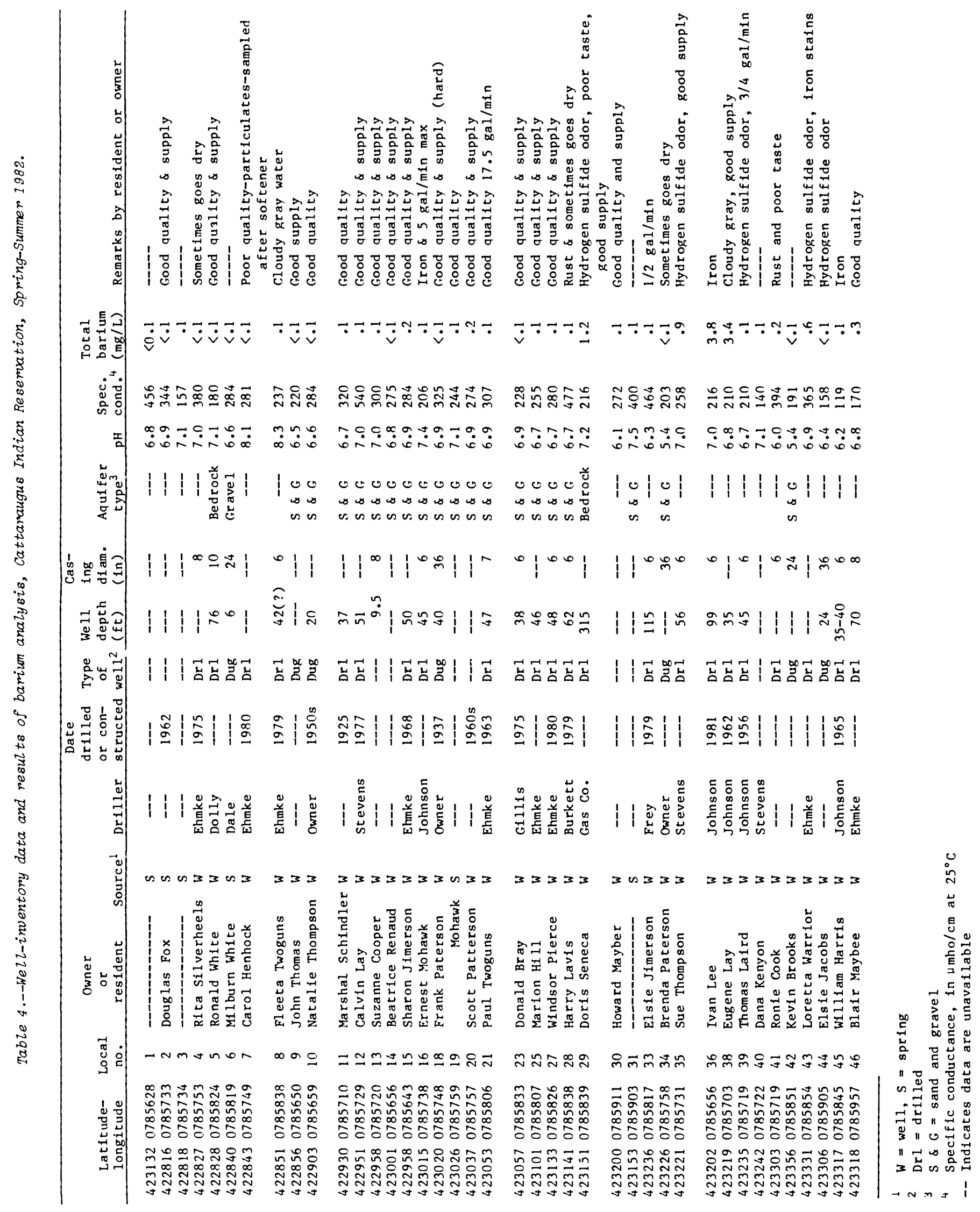




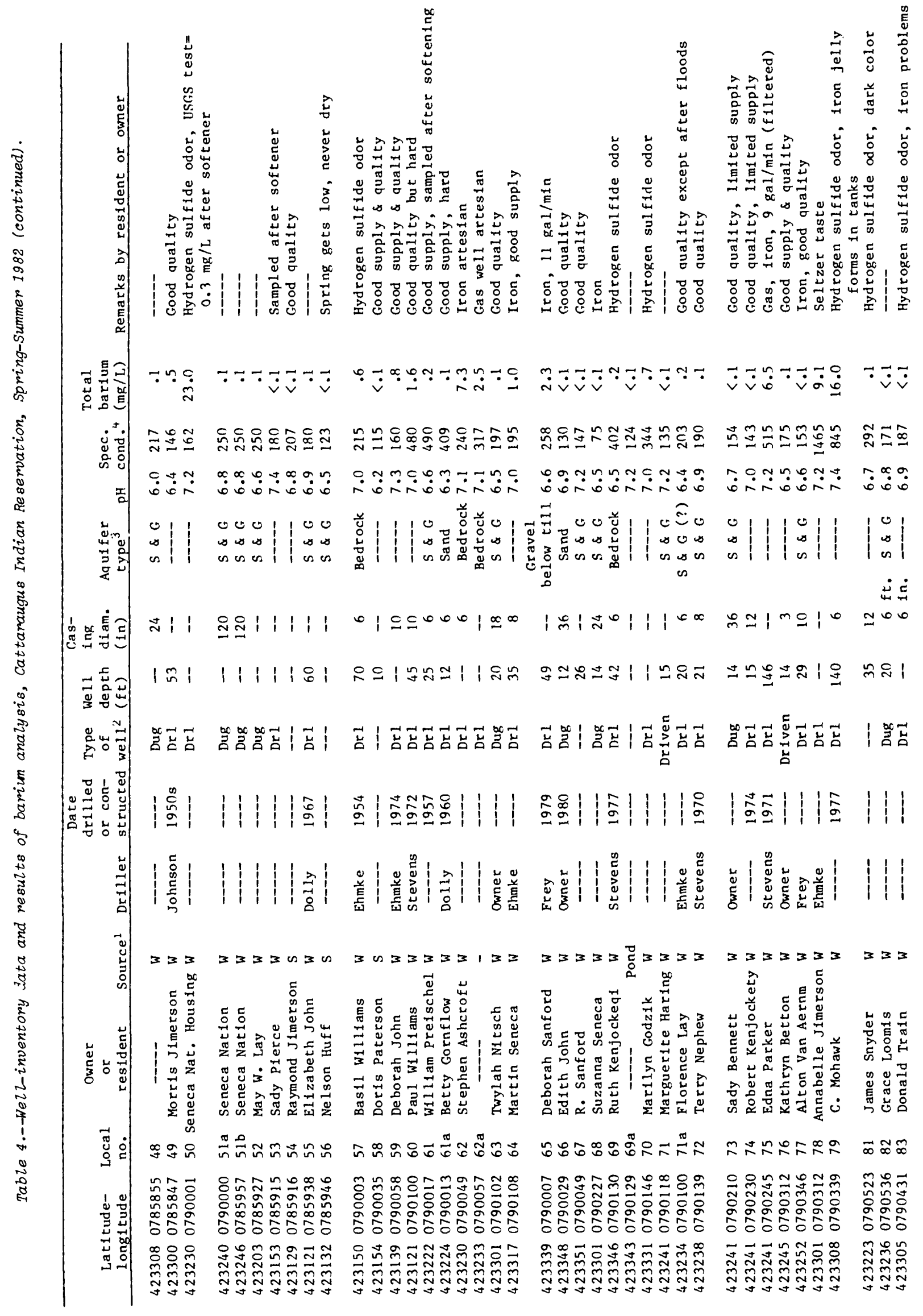




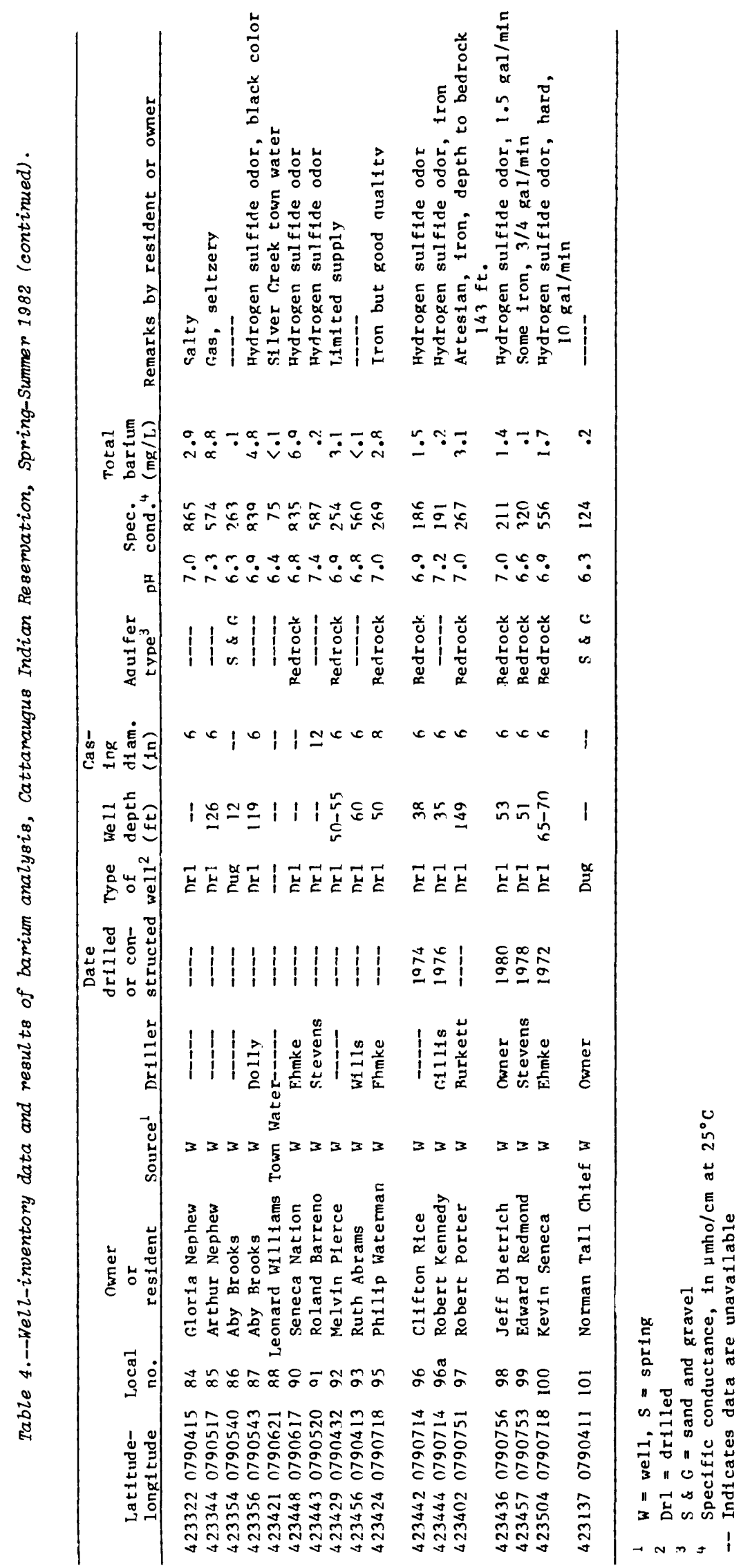

